\title{
Introduction to Special Issue School-Based Approaches to Promote Complete Mental Health: School Psychologists Working to Foster Students' Thriving Well-being
}

\author{
Michael J. Furlong ${ }^{1}$
}

Published online: 9 November 2015

(C) California Association of School Psychologists 2015

\begin{abstract}
This article presents the rationale for and the manuscripts included in a special issue of Contemporary School Psychology, entitled: "School-Based Approaches to Promote Complete Mental Health: School psychologists working to foster students' thriving well-being."
\end{abstract}

Keywords Well-being · Complete mental health · School psychologists $\cdot$ Positive psychology

More than a decade ago, Chafouleas and Bray (2004) had the foresight to develop a major special issue of Psychology in the Schools addressing the topic of "positive psychology and wellness in children." Their efforts challenged school psychologists to consider how positive psychological principles and practices could be used to create more nurturing schools that had the effect of fostering the multiple dimensions of students' well-being. In the subsequent years, it has been increasingly recognized that school psychology, with its roots in child development and education, is inexorably linked with efforts to foster the robust and vital development of all youth-school psychologists recognize that the absence of problems is an insufficient objective because the penultimate prize for school psychologists and their educator colleagues is to help shepherd all children toward competence and meaningful life-long engagement. Ben-Arieh (2008) recognized this positivity principle in a discussion of well-being as a fundamental right, as articulated by a United Nations Convention (Hart and Hart 2014; Nastasi and Borja 2016). This fun-

Michael J. Furlong

mfurlong@education.ucsb.edu

1 Department of Counseling, Clinical, and School Psychology, University of California Santa Barbara, Santa Barbara, CA, USA damental right is grounded in the best interests and optimal development of children because well-being is more than mere survival and not simply the absence of problems or deficiencies.

This special issue of Contemporary School Psychology aims to contribute to the growing literature on approaches that school psychologists can use to better understand and implement practices grounded in positive principles that enhance optional youth development, and, given school psychologists' focus, particularly subjective well-being and complete mental health. The manuscripts examine best practice addressing how school psychologists are working effectively to foster the development of "noncognitive" factors that promote student success and foster the flourishing well-being of all students. These articles provide examples of how school psychologists are engaged in assessment, prevention, and intervention practices that foster the internal assets and external resources that help all students manage life's myriad development tasks in a manner that lead to robust subjective well-being and purposeful life engagement.

Cefai and Cavioni (2015) provide a conceptual frame for the special by arguing that well-being enhancement is not achieved via add-on programs, but that efforts to foster complete student development require sensitivity to and awareness of how to infuse efforts into all school contexts - academic, interpersonal, and extra-curricular-with strategies that promote the thriving well-being of all students. Within the context of a whole school strategy, one important component of school psychologists' efforts has been the development of measures and procedures to monitor students' personal and social assets that are associated with flourishing and thriving development. Ito et al. (2015) provide an example of how the Social Emotional Health Survey-Secondary was adapted for use with Japanese students, such efforts are important to achieve the goal of validating well-being related instruments 
that can be used in research and applied settings cross nationally (Kim et al. 2016). Although the development and refinement of well-validated measures is vital, school psychologists also need to know how to use these measures most effectively in support of school-based well-being enhancing initiatives. To this end, Moore et al. (2015) and Sweeney et al. (2015) present examples of how school psychologists can plan for and implement whole school screening procedures that facilitate school care coordination teams' efforts to foster youths' complete social emotion health. Along this same theme, Pennell et al. (2015) and Heffel et al. (2015) examine how information about students' psychological distress and internal assets at one time are associated with later psychological developmental challenges, which recognizes school psychologists need empirical evidence of how student psychological experiences at the time of screening are associated with later quality of life experiences. Finally, and most vital to changing youths lives, four contributions (Suldo et al. 2015; Wendt et al. 2015; Wang et al. 2015; Claro et al. 2015) provide empirically evaluated psychoeducational strategies that can be used as universal or targeted interventions logically linked with fostering students' high levels of well-being.

School psychologists are encouraged to contact the special issue contributors for more specific information as they consider how to enhance their services in ways that improve the quality of life for all students.

\section{Compliance with Ethical Standards}

Conflict of Interest The author declares that he has no competing interest.

\section{References}

Ben-Arieh, A. (2008). The child indicators movement: past, present, and future. Child Indicators Research, 1, 3-16. doi:10.1007/s12187007-9003-1.

Cefai, C., \& Cavioni, V. (2015). Beyond PISA: schools as contexts for the promotion of children's mental health and well-being. Contemporary School Psychology. doi:10.1007/s40688-015-0065-7.

Chafouleas, S. M., \& Bray, M. A. (Eds.). (2004). Positive psychology and wellness in children (special issue). Psychology in the Schools, 41, $1-172$.

Claro, A., \& Boulanger, M-M., \& Shaw, S. R. (2015). Targeting vulnerabilities to risky behavior: an intervention for promoting adaptive emotion regulation in adolescents. Contemporary School Psychology. doi:10.1007/s40688-015-0063-9.
Hart, S. N., \& Hart, B. W. (2014). Children's rights and school psychology: historical perspective and implications for the profession. School Psychology International, 35, 6-28. doi:10.1177/ 0143034313508875.

Heffel, C. J., Riggs, S. A., \& Ruiz, J. M., \& Ruggles, M. (2015). The aftermath of a suicide cluster in the age of online social networking: a qualitative analysis of adolescent grief reactions. Contemporary School Psychology. doi:10.1007/s40688-015-0060-z.

Ito, A., Smith, D. C., You, S., \& Shimoda, Y., \& Furlong, M. J. (2015). Validation and utility of the social emotional health survey- secondary for Japanese students. Contemporary School Psychology. doi:10.1007/s40688-015-0068-4.

Kim, E. K., Furlong, M. J., Ng, Z. J., \& Huebner, E. S. (2016). Child wellbeing and children's rights: balancing positive and negative indicators in assessments. In S. Hart \& B. K. Nastasi (Eds.), International handbook on child rights in school psychology. New York, NY: Springer

Moore, S. A., \& Widales-Benitez, O., \& Carnazzo, K. W., Kim, E. K., Moffa, K., \& Dowdy, E. (2015). Conducting universal complete mental health screening via student self-report. Contemporary School Psychology. doi:10.1007/s40688-015-0062-x.

Nastasi, B. K., \& Borja, A. P. (Eds.). (2016). International handbook of psychological well-being in children and adolescents: bridging the gaps between theory, research, and practice. New York: Springer Science+Business Media.

Pennell, C., Boman, P., \& Mergler, A. (2015). Covitality constructs as predictors of psychological well-being and depression for secondary school students. Contemporary School Psychology. doi:10.1007/ s40688-015-0067-5.

Suldo, S. M., Hearon, B. V., Bander, B., McCullough, M., Garofano, J., \& Roth, R. A., \& Tan, S. Y. (2015). Increasing elementary school students' subjective well-being through a classwide positive psychology intervention: results of a pilot study. Contemporary School Psychology. doi:10.1007/s40688-015-0061-y.

Sweeney, C., Warner, C. M., Brice, C., \& Stewart, C., Ryan, J., Loeb, K. L., \& McGrath, R. E. (2015). Identification of social anxiety in schools: the utility of a two-step screening process. Contemporary School Psychology. doi:10.1007/s40688-015-0055-9.

Wang, C., Couch, L., Rodriguez, G. R., \& Lee, C. (2015). The Bullying Literature Project: using children's literature to promote prosocial behavior and social-emotional outcomes among elementary school students. Contemporary School Psychology. doi:10.1007/s40688015-0064-8.

Wendt, S., Hipps, J., Abrams, A., Grant, J., Valosek, L., \& Nidich, S. (2015). Practicing transcendental meditation in high schools: relationship to well-being and academic achievement among students. Contemporary School Psychology. doi:10.1007/s40688-015-0066-6.

Michael J. Furlong, PhD is a professor in the Department of Counseling, Clinical, and School Psychology at the University of California Santa Barbara. He is a Fellow of the American Psychological Association (Division 16, School Psychology) and the American Educational Research Association, and a member of Society for the Study of School Psychology. He is a co-editor (with Rich Gilman and E. Scott Huebner) of the Handbook of Positive Psychology in Schools (2014). 